\title{
Effect of bisphenol $F$, an analog of bisphenol $A$, on the reproductive functions of male rats
}

\author{
Asad Ullahn', Madeeha Pirzada', Tayyaba Afsar ${ }^{2}$, Suhail Razak ${ }^{1,2^{*}}$, Ali Almajwal ${ }^{2}$ and Sarwat Jahan ${ }^{1}$
}

\begin{abstract}
Objective: Bisphenol A (BPA) is a monomer primarily used in the production of polycarbonate plastic and epoxy resins. Bisphenol F (BPF) is apparently the main BPA replacement that is used increasingly. BPF has been detected in canned food, thermal paper receipts, and soft drinks. In the present experiment, we did both in vitro and in vivo studies to evaluate the effect of low and high-dose BPF exposures on testosterone concentration, oxidative stress, and antioxidants activity in reproductive tissues of male rats.

Methods: Adult (80-90 days old) male Sprague Dawley rats $(n=36)$ obtained from the rodent colony of Animal Sciences Department of Quaid-i-Azam University. The direct effects of BPF on the antioxidant enzymes and testosterone secretion were measured in vitro and in vivo studies. In an in vivo experiment, adult male Sprague Dawley rats $(n=42)$ were exposed to different concentrations of bisphenol $F(1,5,25$, and $50 \mathrm{mg} / \mathrm{kg} / \mathrm{d}$ ) for 28 days. Various biochemical parameters were analyzed including the level of catalase (CAT), superoxide dismutase (SOD), peroxidase (POD), reactive oxygen species (ROS), and lipid peroxidation (LPO). Moreover, sperm motility, daily sperm production (DSP), comet assay, and histological analysis were performed.
\end{abstract}

Results: In vitro study showed that BPF exposure significantly $(p<0.05)$ induced oxidative stress biomarkers, i.e., ROS and $L P O$, while it did not change antioxidant enzyme and testicular testosterone concentration. Whereas, an in vivo study revealed that BPF induced dose-dependent effect and high-dose $(100 \mathrm{mg} / \mathrm{kg})$ exposure of BPF significantly reduced tissue protein $(p<0.05)$ content, CAT $(p<0.001)$, SOD $(p<0.05)$, and POD $(p<0.05)$ levels while significantly $(p<0.05)$ augmented ROS and lipid peroxidation. Furthermore, BPF reduces testosterone, LH, and FSH secretion in a dosedependent manner. Significant $(p<0.001)$ reduction in plasma and intra-testicular testosterone, LH, and FSH was noticed at $100 \mathrm{mg} / \mathrm{kg}$ BFP dose. High-dose exposure reduces spermatogenesis.

Conclusion: BPF showed an antagonistic effect on male reproductive hormones and induce alterations in testicular morphology. Increased oxidative stress and decreased testicular antioxidant status might be the underlying mechanism of BFP-induced testicular toxicity.

Keywords: Bisphenol F, Male reproductive system, Reproductive toxicity, Antioxidant enzymes, Oxidative stress

\footnotetext{
* Correspondence: ruhail12345@yahoo.com

${ }^{1}$ Reproductive Physiology Lab, Department of Animal Sciences, Quaid-i-Azam

University, Islamabad, Pakistan

2Department of Community Health Sciences, College of Applied Medical

Sciences, King Saud University, Riyadh, Kingdom of Saudi Arabia
}

(c) The Author(s). 2019 Open Access This article is distributed under the terms of the Creative Commons Attribution 4.0 International License (http://creativecommons.org/licenses/by/4.0/), which permits unrestricted use, distribution, and reproduction in any medium, provided you give appropriate credit to the original author(s) and the source, provide a link to the Creative Commons license, and indicate if changes were made. The Creative Commons Public Domain Dedication waiver (http://creativecommons.org/publicdomain/zero/1.0/) applies to the data made available in this article, unless otherwise stated. 


\section{Introduction}

Bisphenol A (BPA) is a monomer primarily used in the production of polycarbonate plastics and epoxy resins [1, 2]. BPA used in thermal papers does not bind covalently with macromolecules of polymer, and with ease migrates into food and beverages [2]. BPA's possible route of exposure in humans is food, drinking water, and beverages except for occupational exposure [3]. Studies have shown that beverages in cans are more contaminated with BPA and its analog than those packed in glass containers [2]. Following the restrictions on the use of BPA in the canning industry moving towards safer alternatives of BPA [4], among the BPA alternatives, a large class of compounds shares chemical and physical properties with BPA with variable toxicity and higher estrogenic activities. Among this group of compounds, bisphenol F (BPF) is apparently the main replacement to BPA. BPF has been detected in canned food, thermal paper receipts, and soft drinks. BPF has also exhibited endocrine-modulating capabilities and its toxicity has also shown genotoxic effects, carcinogenic potencies, reproductive complacencies, and oxidative stress [5-8].

$\mathrm{BPF}$ has a wide spectrum use in the plastic industry and it has been detected in 55 of the 100 tested urine samples with a concentration of $0.08 \mu \mathrm{g} / \mathrm{L}$ [9]. Similar, concentrations of BPF were observed from 600 urine samples collected in the US from 2000 to 2014 with a concentration of $0.15-0.54 \mu \mathrm{g} / \mathrm{L}[10,11]$. HepG2 cell line treated with $\mathrm{BPF}$ resulted in oxidative stress and endocrine activities. In another study on HepG2 cells, it was observed that BPF has a higher affinity for ER $\alpha$ and $\beta$ receptors than that of other bisphenols [12-14]. Significantly less information about potential adverse health outcomes is available about BPF regarding its toxicity. Similar to BPA, BPF is an endocrine-disrupting chemical and displays hormonal activity, with similar average estrogenic, androgenic, and antiestrogen potencies across different in vitro assays. BPF differentially affects signaling pathways involved in lipid metabolism and adipogenesis and causes DNA damage. The present study aimed to examine the possible effects of BPF exposure on the reproductive system of mammals by using rats as an animal model.

\section{Methods}

\section{Chemicals}

Bisphenol F (BPF) with 99\% purity was purchased from Santa Cruz Biotechnologies, USA. For the in vitro experiment, different materials as fetal bovine serum, penicillin/streptomycin, and Dulbecco's modified Eagle's medium (DMEM) were obtained from Thermos Fisher Scientific (Waltham, MA, USA). CAT, N-acetyl-L-cysteine (NAC) and $\mathrm{H}_{2} \mathrm{O}_{2}, \mathrm{Ca}^{2+}, \mathrm{Mg}^{2+}$, Hank's balanced salt solution (HBSS) were bought from Sigma-Aldrich (St. Louis, MO, USA).

\section{Animals}

Sprague Dawley adult male rats (age 80-90 days) were obtained from the animal facility of Quaid-i-Azam University, Islamabad. Prior to the start of the experiment standard laboratory conditions were maintained. Animals were fed with laboratory feed and tap water was available freely for the animals. Protocols of handling of the animals were approved by the animal sciences department ethical committee.

\section{Experimental design}

For bisphenol F (BPF) exposure on male rats, different experiments were conducted. Firstly, we conducted an in vitro experiment in which the direct effects of BPF on the levels of antioxidant enzymes and different concentrations of testosterone in the testis of rats were tested. While on the results of the in vitro study, an in vivo study was conducted in which the effects of different concentrations of BPF on the reproductive system of male rats were evaluated through subchronic study.

\section{In vitro studies}

In the in vitro study, a total of ( $n=36$ and $n=6$ animals per group) Sprague Dawley male adult rats were used. In order to investigate the direct effects of BPF on the antioxidant enzymes and testosterone production, an in vitro study was conducted. In this study, different doses of $\operatorname{BPF}(0,1,10,25,50$, and $100 \mathrm{ng} / \mathrm{ml})$ were prepared in ethanol which was in accordance with $[15,16]$. The culturing of testicular tissues was done by the method of [16] with little modifications. Healthy male rats were euthanized and the testes were removed and placed in clean Petri dishes and were cut in equal parts and placed in culture tubes. Culture media containing Dulbecco's, penicillin, sodium bicarbonate, and streptomycin were mixed with $0,1,10,25,50$, and $100 \mathrm{ng} / \mathrm{ml}$ of BPF with the method explained elsewhere by [17]. All the culture tubes containing media, testicular tissues, and BPF different concentrations were incubated in a carbon dioxide $\left(\mathrm{CO}_{2}\right)$ incubator for 2 hours. After the incubation period, all the incubated tissues were washed with saline and homogenized in $30 \mathrm{ml}$ of phosphate buffer saline (PBS) and centrifuged at 30,000 for $30 \mathrm{~min}$. Then the supernatant was collected and stored at $-80^{\circ} \mathrm{C}$ for further investigation.

\section{In vivo study}

Adult male Sprague Dawley rats $(n=42)$ were divided into six groups ( $n=7$ /group) by randomization procedures explained elsewhere [18]. All the animals were exposed to different concentrations $(1,5,25,50$, and 100 $\mathrm{mg} / \mathrm{kg}$ body weight/ day) of BPF for 28 days.

Group 1: Control received saline

Group 2: Administration of BPF at a dose of $1 \mathrm{mg} / \mathrm{kg}$ body weight/day 
Group 3: Administration of BPF at a dose of $5 \mathrm{mg} / \mathrm{kg}$ body weight/day

Group 4: Administration of BPF at a dose of $25 \mathrm{mg} / \mathrm{kg}$ body weight/day

Group 5: Administration of BPF at a dose of $50 \mathrm{mg} / \mathrm{kg}$ body weight/day

Group 6: Administration of BPF at a dose of $100 \mathrm{mg} /$ $\mathrm{kg}$ body weight/day

No mortality was recorded during the period of experimentation. At the end of the experiment (on the 29th day), animals were euthanized and different organs were dissected and stored at $-80^{\circ} \mathrm{C}$ for different tests. Blood was collected and centrifuged at $3000 \mathrm{rpm}$ for 10 mins and plasma was separated and stored at $-20^{\circ} \mathrm{C}$ for hormonal and different biochemical analysis by the researcher blind to the treatment groups. The reproductive organs as testicular tissues (left testis and left epididymis) were weighed and processed for antioxidant enzymes while right testis (transverse sections) and right epididymis were fixed in $10 \%$ formalin for histological analysis as explained by [19].

\section{Biochemical analysis}

Tissues collected from both in vitro and in vivo studies were further processed for the antioxidant enzymes and oxidative stress markers. Tissues were homogenized with an automatic homogenizer in phosphate buffer saline (PBS) and centrifuged at $30,000 \mathrm{rpm}$ for 30 mins. After the centrifugation, the supernatant was removed and used for the hormonal analysis, protein estimation, and antioxidant enzymes $[17,19]$.

\section{Catalase (CAT)}

Afsar et al.'s method was used to determine the catalase (CAT) activity [20], and the change in the absorbance was measured in the tissues. In this assay $50 \mathrm{ml}$, the homogenate was diluted in $2 \mathrm{ml}$ of phosphate buffer with a $\mathrm{pH}$ of 7.0. After mixing it thoroughly the absorbance was read at $240 \mathrm{~nm}$ with an interval of $15 \mathrm{~s}$ and 30 s. Change in the absorbance of 0.01 as unit/min was defined as one unit of CAT.

\section{Superoxide dismutase (SOD)}

Afsar and colleagues method was used to determine the superoxide dismutase (SOD) activity [21]. In this assay, the amount of chromogen formed was measured at $560 \mathrm{~nm}$. The results were expressed in units per milligram of protein.

\section{Peroxidase (POD)}

Peroxidase (POD) activity in the homogenate was determined by the spectrophotometric method of Carlberg and Mannervik, [22]. In this assay, the homogenate was mixed with $0.1 \mathrm{ml}$ of guaiacol, $0.3 \mathrm{ml}$ of $\mathrm{H}_{2} \mathrm{O}_{2}$, and 2.5 $\mathrm{ml}$ of phosphate buffer and the absorbance was read at
$470 \mathrm{~nm}$. Change in the absorbance of 0.01 as unit per minute was defined as one unit of POD.

\section{Lipid peroxidation (LPO)}

The activity of lipid peroxidation by T-BARS was determined in the homogenate by the method used by Iqbal and coworkers [23] and the results were expressed as TBARS per minute per milliliters of plasma. In this assay, $0.1 \mathrm{ml}$ of homogenate was mixed with $0.29 \mathrm{ml}$ phosphate buffer, $0.1 \mathrm{ml}$ of trichloroacetic acid, and $1 \mathrm{ml}$ of trichlorobarbituric acid followed by heating at $95^{\circ} \mathrm{C}$ for $20 \mathrm{~min}$ and then shifted to an ice bath before centrifuging at $2500 \mathrm{rpm}$ for $10 \mathrm{~min}$. The samples were read with the help of spectrophotometer at $535 \mathrm{~nm}$.

\section{Reactive oxygen species (ROS)}

The assay of reactive oxygen species (ROS) was done according to the method of Hayashi et al. [24]. In this assay, $5 \mathrm{ml}$ of $\mathrm{H}_{2} \mathrm{O}_{2}$ standards and the homogenate was mixed with $140 \mathrm{ml}$ of sodium acetate buffer with $\mathrm{pH} 4.8$ in 96-well plates and incubated at $37^{\circ} \mathrm{C}$ for $5 \mathrm{~min}$. After the incubation, $100 \mathrm{ml}$ of DEPPD and ferrous sulphate mix samples were added in each well with a ratio of 1:25 and were incubated at $37^{\circ} \mathrm{C}$ for $1 \mathrm{~min}$. With an interval of $15 \mathrm{~s}$ for $3 \mathrm{~min}$, the absorbance was read at $505 \mathrm{~nm}$ at microplate reader.

\section{Protein estimation}

Determination of total protein content in tissues was done following a commercial diagnostic kit (AMEDA Labordiagnostik Laboratory, Austria) protocol. The results of protein were measured by plotting absorbance of the standard against samples. These values were expressed as milligram per gram of tissue.

\section{Hormonal analysis}

Quantitative EIA kits were used for the measurement of testosterone (BioCheck Inc., USA Catalog No. BC-1115), luteinizing hormone (LH) (BioCheck Inc., USA Catalog No.BC-1031), and follicle-stimulating hormone (FSH) (BioCheck Inc., USA Catalog No.BC-1029) concentrations in the tissues and the assays were performed by the instructions with the kits. All the above assays were repeated with both inter- and intra-assay variations for more and precise results.

\section{Tissue histopathology}

Testicular tissues (testis and epididymis) were fixed in formalin for $48 \mathrm{~h}$, dehydrated with different grades of alcohol, and cleared with the help of xylene. The paraffin sections $(5 \mu \mathrm{m})$ were cut and stained with hematoxylin and eosin for histology and morphometry. Transverse sections (1020/group) of testicular tissues were examined under a Leica 
Microscope (New York Microscope Company) equipped with a digital camera (Canon, Japan).

For the morphometry, the images were taken at $\times 20$ and $\times 40$, and the results were done with Image $J$ software. Area of different sections was calculated with the method of Jensen et al. [25]. From $\times 20$ images, 30 pictures per animal were selected and the known area of different areas of intestinal space, epididymis tubules, and seminiferous tubules was measured by the software. The number of different cell types (spermatids, spermatogonia, and spermatocytes) and the area were calculated, and comparison of different groups with control was done.

\section{Statistical analysis}

All parameters of data points showed normal distribution and hence were reported as mean \pm SEM and difference was considered significant at $P<0.05$. One way ANOVA followed by Dunnet's multiple comparison tests was used for the comparison of different groups with control using Graph Pad Prism software.

\section{Results}

\section{Bisphenol $F$ in vitro effects on the testicular tissues} antioxidants, ROS and testosterone secretions in the rat testis

Antioxidant enzymes, i.e., CAT, POD and SOD, oxidative stress markers, i.e., reactive oxygen species (ROS) and TBARS, were determined in the testicular tissues after 2 hours incubation with different concentrations of BPF (Table 1). There was no significant difference observed in the CAT, POD, and SOD activity in any of the BPF-treated groups as compared to the control.

Reactive oxygen species and LPO are considered important oxidative stress markers. In BPF $50 \mathrm{ng} / \mathrm{ml}$ and $100 \mathrm{ng} / \mathrm{ml}$ treated groups, significant $(P<0.05)$ increases in LPO were observed as compared to the control. However, there was no significant increase observed in the low-dose-treated groups as compared to the control. Similarly, there is a dose-dependent augmentation in
ROS levels in different treatment groups. In BPF $25 \mathrm{ng} /$ $\mathrm{ml}$ and $50 \mathrm{ng} / \mathrm{ml}$, significant $(P<0.05)$ increase in ROS was noticed, whereas in BPF $100 \mathrm{ng} / \mathrm{ml}$, marked $(P<$ 0.01 ) increase in ROS was examined as compared to the control group. Low doses of BPF did not induce any change in ROS level compared to the control group.

The levels of testosterone in the testis after 2 hour incubation with the treatment of different concentrations of BPF decreased but that difference was not significant as compared to control (Table 1).

\section{Bisphenol $\mathrm{F}$ different concentration effects on the body weight gain and testicular weight after sub-chronic administration}

BPF exposure in male rats for 28 days did not show any significant change in the body weight of all treated groups as compared to the control. There was also no significant difference observed in the left testis and right testis of all the treated groups with BPF when compared to the control (Table 2).

\section{Bisphenol $\mathrm{F}$ different concentration sub-chronic effects on the biochemical parameters of rat testis}

Antioxidant enzymes in the testicular tissues after 28 days of different concentrations of subchronic exposure to BPF and control are presented in Table 2. There was no significant difference observed in the activity of SOD when different treatment groups of BPF were compared with control. On the other hand, there was a significant difference observed in the activity of POD when different treated groups of BPF were compared with control. A significant reduction was observed in BPF $5 \mathrm{mg} / \mathrm{kg}(P<0.05)$, BPF $25 \mathrm{mg} / \mathrm{kg}$ $(P<0.01)$, BPF $50 \mathrm{mg} / \mathrm{kg}(P<0.05)$, and BPF $100 \mathrm{mg} / \mathrm{kg}$ $(P<0.05)$ when compared to the control.

BPF treatment caused significant $(P<0.05)$ reduction in CAT activity at doses of 5,25 , and $50 \mathrm{mg} / \mathrm{kg}$ treated groups as compared to control. Similarly, BPF treatment caused significant $(P<0.01)$ decline in CAT activity at dose levels of $100 \mathrm{mg} / \mathrm{kg}$ treated groups.

ROS and LPO level in different treatment groups are presented in Table 2. LPO which is a well-known oxidative

Table 1 In vitro effect of Bisphenol F (BPF) on antioxidant enzymes and testosterone secretion in rat testis

\begin{tabular}{|c|c|c|c|c|c|c|}
\hline \multirow{2}{*}{$\begin{array}{l}\text { Groups ( } n= \\
\text { 6/group) }\end{array}$} & \multicolumn{6}{|l|}{ Parameters } \\
\hline & $\begin{array}{l}\text { CAT (u/ } \\
\text { mgProtein) }\end{array}$ & $\begin{array}{l}\text { POD } \\
\text { (nmole) }\end{array}$ & $\begin{array}{l}\text { SOD (u/ } \\
\text { mgprotein) }\end{array}$ & $\begin{array}{l}\text { LPO (nM TBARS/min/mg } \\
\text { Tissue) }\end{array}$ & $\begin{array}{l}\text { Total ROS }(\mathrm{U} / \mathrm{g} \\
\text { tissue) }\end{array}$ & $\begin{array}{l}\text { Testosterone (ng/g } \\
\text { tissue) }\end{array}$ \\
\hline Control & $9.53 \pm 0.43$ & $8.12 \pm 0.60$ & $10.51 \pm 1.78$ & $31.11 \pm 1.81$ & $29.00 \pm 2.32$ & $52.32 \pm 2.02$ \\
\hline BPF $1 \mathrm{ng} / \mathrm{ml}$ & $8.39 \pm 0.53$ & $7.43 \pm 0.79$ & $11.99 \pm 2.01$ & $24.17 \pm 1.11$ & $35.60 \pm 2.35$ & $49.04 \pm 2.45$ \\
\hline BPF $5 \mathrm{ng} / \mathrm{ml}$ & $7.94 \pm 0.49$ & $6.92 \pm 1.13$ & $12.08 \pm 2.23$ & $40.07 \pm 2.56$ & $29.60 \pm 2.08$ & $46.48 \pm 1.60$ \\
\hline BPF $25 \mathrm{ng} / \mathrm{ml}$ & $7.95 \pm 0.85$ & $6.46 \pm 1.28$ & $13.66 \pm 2.10$ & $39.21 \pm 2.85$ & $38.60 \pm 2.47^{*}$ & $44.71 \pm 2.31$ \\
\hline BPF $50 \mathrm{ng} / \mathrm{ml}$ & $7.80 \pm 1.29$ & $7.06 \pm 1.85$ & $13.15 \pm 0.32$ & $46.97 \pm 4.97^{*}$ & $39.00 \pm 2.44^{*}$ & $48.76 \pm 2.31$ \\
\hline $\begin{array}{l}\text { BPF } 100 \mathrm{ng} / \\
\mathrm{ml}\end{array}$ & $7.59 \pm 1.04$ & $7.86 \pm 0.71$ & $14.71 \pm 0.85$ & $46.91 \pm 4.53^{*}$ & $41.40 \pm 1.89^{* *}$ & $47.14 \pm 3.23$ \\
\hline
\end{tabular}

Values are expressed as mean \pm SEM. ${ }^{*}, * *, * *$ Significant difference at probability value $P<0.05, P<0.01$, and $P<0.001$ compared to control, respectively. ANOVA followed by Dunnett's comparison test. BPF Bisphenol F 
Table 2 In vivo effect of subchronic Bisphenol F (BPF) on the different parameters

\begin{tabular}{lllllll}
\hline Parameter & \multicolumn{3}{l}{ Treatments $(n=7 / \mathrm{group})$} & & \\
\cline { 2 - 6 } & Control & BPF $1 \mathrm{mg} / \mathrm{kg}$ & BPF $5 \mathrm{mg} / \mathrm{kg}$ & BPF 25 mg/kg & BPF 50 mg/kg & BPF 100 mg/kg \\
\hline Body weight gain (g) & $35.00 \pm 4.33$ & $26.90 \pm 5.23$ & $25.10 \pm 3.21$ & $25.00 \pm 4.33$ & $29.20 \pm 5.12$ & $27.00 \pm 4.33$ \\
Right Testis weight (g) & $1.04 \pm 0.05$ & $1.18 \pm 0.03$ & $1.02 \pm 0.03$ & $1.14 \pm 0.06$ & $1.22 \pm 0.05$ & $1.12 \pm 0.07$ \\
Left testis weight (g) & $1.16 \pm 0.02$ & $1.16 \pm 0.04$ & $1.12 \pm 0.02$ & $1.14 \pm 0.05$ & $1.16 \pm 0.03$ & $1.12 \pm 0.05$ \\
SOD (u/mg protein) & $45.14 \pm 1.19$ & $34.29 \pm 3.75$ & $34.38 \pm 1.48$ & $36.26 \pm 5.03$ & $31.97 \pm 4.63$ & $32.54 \pm 3.38$ \\
POD (nmole) & $16.55 \pm 0.43$ & $15.18 \pm 0.67$ & $13.70 \pm 1.12^{*}$ & $12.35 \pm 0.39^{* *}$ & $13.15 \pm 0.64^{* *}$ & $13.71 \pm 0.68^{*}$ \\
CAT (u/mg Protein) & $16.08 \pm 0.73$ & $14.12 \pm 1.01$ & $13.03 \pm 0.57^{*}$ & $12.99 \pm 0.70^{*}$ & $12.91 \pm 1.01^{*}$ & $11.59 \pm 0.59^{* *}$ \\
LPO (min/mg Tissue) & $13.13 \pm 0.73$ & $12.02 \pm 0.80$ & $13.35 \pm 0.32$ & $14.93 \pm 0.58$ & $15.35 \pm 0.38^{*}$ & $15.62 \pm 0.50^{*}$ \\
Total ROS (U/g tissue) & $0.94 \pm 0.20$ & $0.89 \pm 0.05$ & $0.96 \pm 0.20$ & $2.29 \pm 0.42$ & $2.78 \pm 0.47^{*}$ & $3.11 \pm 0.61^{* *}$ \\
Protein (mg/0.5 g) & $341.91 \pm 6.45$ & $287.90 \pm 21.72$ & $280.23 \pm 6.62^{*}$ & $278.90 \pm 11.16^{*}$ & $274.77 \pm 7.90^{*}$ & $267.81 \pm 12.44^{* *}$ \\
\hline
\end{tabular}

Values are expressed as mean $\pm \mathrm{SEM} .{ }^{*},{ }^{* *},{ }^{* * *}$ Significant difference at probability value $\mathrm{P}<0.05, \mathrm{P}<0.01$, and $\mathrm{P}<0.001$ compared to control, respectively. ANOVA followed by Dunnett's comparison test. SOD superoxide dismutase, $P O D$ peroxidase, CAT catalase, $L P O$ lipid peroxidation, ROS reactive oxygen species

stress marker was determined in the reproductive tissues. A significant $(P<0.05)$ increase in the LPO content was observed in BPF $50 \mathrm{mg} / \mathrm{kg}$ and BPF $100 \mathrm{mg} / \mathrm{kg}$ treated groups when compared to control. However, the other doses of BPF did not show a significant effect as compared to control.

Similarly, a significant increase in ROS level was observed in BPF $50 \mathrm{mg} / \mathrm{kg}(P<0.05)$ when compared to control. Total ROS was increased significantly $(P<$ 0.001 ) in BPF $100 \mathrm{mg} / \mathrm{kg}$ as compared to control. However, total ROS was not altered by BPF 1, 5, and $25 \mathrm{mg} /$ $\mathrm{kg}$ groups when compared to the control.

Total protein in the testis showed a significant reduction in BPF $5 \mathrm{mg} / \mathrm{kg}(P<0.05)$, BPF $25 \mathrm{mg} / \mathrm{kg}(P<0.05)$, and BPF $50 \mathrm{mg} / \mathrm{kg}(P<0.05)$ as compared to the control. On the other hand, BPF $100 \mathrm{mg} / \mathrm{kg}$ treatment group showed a significant reduction $(P<0.01)$ in protein levels as compared to control.

\section{Bisphenol $\mathrm{F}$ effects on the different hormones of male rats administrated with different concentrations for 28 days}

Plasma testosterone, LH, FSH, and intra-testicular testosterone in the BPF different treated groups and control is presented in Table 3. Testosterone concentration was reduced significantly $(P<0.05)$ in BPF $25 \mathrm{mg} / \mathrm{kg}$ and 50 $\mathrm{mg} / \mathrm{kg}$ treated groups. Similarly, BPF treatment caused a significant reduction $(P<0.01)$ at a dose level of $100 \mathrm{mg} /$ $\mathrm{kg}$. However, BPF in 1 and $5 \mathrm{mg} / \mathrm{kg}$ treated groups did not affect testosterone concentrations significantly.

Plasma LH concentrations reduced significantly in BPF 25 and $50 \mathrm{mg} / \mathrm{kg}(P<0.05)$ as compared to the control. A significant reduction $(P<0.01)$ was also observed in BPF $100 \mathrm{mg} / \mathrm{kg}$ when compared to the control. On the other hand, BPF 1 and $5 \mathrm{mg} / \mathrm{kg}$ doses did not reduce plasma $\mathrm{LH}$ concentrations as compared to the control.

FSH reduced significantly in BPF $25 \mathrm{mg} / \mathrm{kg}(P<0.01)$ as compared to the control. A significant reduction $(P<$ 0.001) was also observed in BPF 50 and $100 \mathrm{mg} / \mathrm{kg}$ when compared to the control. On the other hand, BPF 1 and $5 \mathrm{mg} / \mathrm{kg}$ treatment did not reduce plasma FSH concentrations as compared to the control.

Intra-testicular testosterone in the testis after 28 days of exposure showed a significant reduction in BPF 25, 50, and $100 \mathrm{mg} / \mathrm{kg}(P<0.01, P<0.001$, and $P<0.01$, respectively) as compared to the control. Intra-testicular testosterone was not different in BPF 1 and $5 \mathrm{mg} / \mathrm{kg}$ treated groups than control (Table 3).

Table 3 Subchronic effect of Bisphenol F (BPF) on the intra-testicular testosterone, plasma testosterone, luteinizing hormone (LH), and follicle-stimulating hormone (FSH) production in rats

\begin{tabular}{|c|c|c|c|c|}
\hline \multirow{2}{*}{$\begin{array}{l}\text { Groups } \\
\text { (n=7/group) }\end{array}$} & \multicolumn{4}{|l|}{ Parameters } \\
\hline & Plasm testosterone $(\mathrm{ng} / \mathrm{ml})$ & Intra-testicular testosterone (ng/g tissue) & LH (ng/ml) & FSH (IU/ml) \\
\hline Control & $6.03 \pm 0.35$ & $55.32 \pm 1.14$ & $1.71 \pm 0.07$ & $0.92 \pm 0.01$ \\
\hline BPF 1 mg/kg & $4.48 \pm 0.50$ & $52.44 \pm 2.71$ & $1.62 \pm 0.09$ & $0.83 \pm 0.03$ \\
\hline BPF 5 mg/kg & $4.34 \pm 0.51$ & $51.48 \pm 2.01$ & $1.52 \pm 0.05$ & $0.76 \pm 0.10$ \\
\hline BPF 25 mg/kg & $3.99 \pm 0.64 *$ & $46.71 \pm 1.87^{* *}$ & $1.43 \pm 0.05^{*}$ & $0.63 \pm 0.02^{* *}$ \\
\hline BPF 50 mg/kg & $3.69 \pm 0.53 *$ & $44.16 \pm 1.14$ *** & $1.39 \pm 0.07^{*}$ & $0.59 \pm 0.02^{* * *}$ \\
\hline BPF 100 mg/kg & $3.20 \pm 0.25^{* *}$ & $45.34 \pm 1.04 * *$ & $1.20 \pm 0.04^{* * *}$ & $0.44 \pm 0.03^{* * * *}$ \\
\hline
\end{tabular}

Values are expressed as mean \pm SEM. ${ }^{*},{ }^{* *},{ }^{* *}$ Significant difference at probability value $P<0.05, P<0.01$, and $P<0.001$ compared to control, respectively. ANOVA followed by Dunnett's comparison test 


\section{Morphological changes in testes and epididymis after exposure to bisphenol $F$ (BPF)}

Effect of BPF exposure on the seminiferous tubule area, interstitium area, seminiferous tubules diameter, and epithelial height in testicular tissue are presented in Table 4 and Fig. 1. There was no significant difference observed in the (\%) area of seminiferous tubule and (\%) area of interstitium of different treatment groups of BPF as compared to control. Similarly, a non-significant difference was observed in the diameter of seminiferous tubules in all treated groups as compared to control. There was significant $(P<0.0 .5)$ reduction in epithelial height in BPF 50 $\mathrm{mg} / \mathrm{kg}$ and $100 \mathrm{mg} / \mathrm{kg}$ groups when compared to the control. On the other hand, epithelial height was not different in BPF 1,5 , and $25 \mathrm{mg} / \mathrm{kg}$ treated groups than the control.

Transverse sections of testicular tissues of the control group were observed with thick epithelium, sperm-filled lumen, and seminiferous tubules (Fig. 1). Seminiferous tubule arrangement and shape was not very different in all treated groups when compared to the control. Though the pattern of epithelium was thin and the number of secondary spermatocytes was reduced in the treated groups when compared to the control. However, the groups with the higher doses of BPF were observed with few tubules and there were very few elongated spermatids in the lumen when these groups were compared with the control (Fig. 1).

Morphometry of different parameters of caput and cauda epididymis region after different BPA exposures did not show any significant difference in any of the parameter (tubular and lumen diameter, epithelial height, and percentage of epithelium and lumen) as compared to the control presented in Table 4 and Fig. 2. The shape of cauda and caput of the epididymis in the control was not very different from that of the treated groups. In the groups treated with 25,50 , and $100 \mathrm{mg} / \mathrm{kg} /$ day there were few empty lumens observed in each epididymis section when compared to the control though there was no loss of stereocilia observed.

The number of different cell types in the seminiferous tubules presented in Fig. 3. A significant difference was not observed in any of the treated group with different concentrations of BPF as compared to the control. Though the number of cells like spermatids and spermatocytes had decreased in some of the treated groups when compared to the control, the reduction was not statistically different when the comparison was done with the control.

\section{Discussion}

Although numerous studies have been published on the effects of BPA on the reproductive functions of male rats, the underlying mechanisms remain unclear. BPA displays non-monotonic dose-response functions [26]. Current knowledge on the biological and potential toxicological effects of BPA analog, especially on the reproductive system, is limited. The main purpose of the current study was to understand how safe is the BPA analog "BPF" from the medical point of view using rat models. Increased exposure of BPA during the prepubertal and pubertal period may affect the normal development and functions of reproductive organs, and the

Table 4 Oral subchronically administered rats with Bisphenol F (BPF) testis, caput, and cauda epididymis morphometry after 28 days of exposure

\begin{tabular}{|c|c|c|c|c|c|c|c|}
\hline \multicolumn{2}{|c|}{ Parameter } & \multicolumn{6}{|c|}{ Treatments ( $n=7 /$ group) } \\
\hline & & Control & BPF $1 \mathrm{mg} / \mathrm{kg}$ & BPF $5 \mathrm{mg} / \mathrm{kg}$ & BPF $25 \mathrm{mg} / \mathrm{kg}$ & BPF 50 mg/kg & BPF $100 \mathrm{mg} / \mathrm{kg}$ \\
\hline \multirow[t]{4}{*}{ Testis } & Area of seminiferous tubule (\%) & $90.02 \pm 0.98$ & $88.85 \pm 2.18$ & $88.87 \pm 2.34$ & $87.37 \pm 1.34$ & $86.73 \pm 1.41$ & $85.65 \pm 2.56$ \\
\hline & Area of Interstitium (\%) & $19.02 \pm 0.79$ & $18.20 \pm 0.88$ & $17.43 \pm 0.37$ & $17.27 \pm 0.54$ & $16.88 \pm 0.41$ & $15.90 \pm 1.50$ \\
\hline & Seminiferous tubule diameter $(\mu \mathrm{m})$ & $213.91 \pm 2.51$ & $211.08 \pm 5.49$ & $209.09 \pm 2.81$ & $208.98 \pm 0.72$ & $207.48 \pm 0.84$ & $207.47 \pm 1.48$ \\
\hline & Epithelial height & $77.27 \pm 1.94$ & $74.47 \pm 1.95$ & $73.71 \pm 3.02$ & $72.38 \pm 1.40$ & $69.16 \pm 1.30^{*}$ & $68.13 \pm 2.07^{*}$ \\
\hline \multirow[t]{5}{*}{ Caput } & Tubular diameter $(\mu \mathrm{m})$ & $403.40 \pm 6.76$ & $399.60 \pm 4.28$ & $398.20 \pm 3.78$ & $396.20 \pm 3.94$ & $394.80 \pm 4.61$ & $396.40 \pm 2.97$ \\
\hline & Lumen diameter ( $\mu \mathrm{m})$ & $300.00 \pm 7.05$ & $298.60 \pm 7.50$ & $295.00 \pm 4.14$ & $297.20 \pm 4.57$ & $292.60 \pm 4.82$ & $290.60 \pm 4.34$ \\
\hline & Epithelial height ( $\mu \mathrm{m})$ & $31.40 \pm 1.80$ & $29.40 \pm 3.84$ & $28.00 \pm 1.41$ & $28.20 \pm 3.10$ & $27.00 \pm 0.83$ & $26.60 \pm 1.16$ \\
\hline & Epithelium (\% age) & $37.95 \pm 1.99$ & $34.20 \pm 1.01$ & $33.60 \pm 0.81$ & $32.80 \pm 1.49$ & $32.40 \pm 2.59$ & $32.00 \pm 0.63$ \\
\hline & Lumen (\% age) & $70.85 \pm 1.65$ & $69.00 \pm 3.21$ & $67.86 \pm 1.78$ & $67.25 \pm 0.91$ & $68.34 \pm 2.40$ & $66.25 \pm 7.74$ \\
\hline \multirow[t]{5}{*}{ Cauda } & Tubular diameter $(\mu \mathrm{m})$ & $482.80 \pm 4.58$ & $478.60 \pm 3.60$ & $476.60 \pm 5.26$ & $477.80 \pm 4.03$ & $475.80 \pm 6.51$ & $474.80 \pm 4.03$ \\
\hline & Lumen diameter ( $\mu \mathrm{m})$ & $432.60 \pm 2.98$ & $436.80 \pm 4.68$ & $435.20 \pm 4.65$ & $441.00 \pm 4.32$ & $438.80 \pm 0.96$ & $439.20 \pm 3.36$ \\
\hline & Epithelial height $(\mu \mathrm{m})$ & $33.25 \pm 2.32$ & $34.50 \pm 1.79$ & $35.75 \pm 0.49$ & $35.80 \pm 4.03$ & $36.20 \pm 2.07$ & $38.40 \pm 3.40$ \\
\hline & Epithelium (\% age) & $39.00 \pm 1.54$ & $43.75 \pm 1.89$ & $44.75 \pm 2.10$ & $42.75 \pm 2.41$ & $44.10 \pm 1.73$ & $45.00 \pm 1.18$ \\
\hline & Lumen (\% age) & $63.25 \pm 1.45$ & $60.00 \pm 2.87$ & $62.25 \pm 1.73$ & $60.50 \pm 2.77$ & $59.25 \pm 3.04$ & $58.65 \pm 2.47$ \\
\hline
\end{tabular}

Values are expressed as mean \pm SEM. *Significant difference at probability value $P<0.05$ compared to control. ANOVA followed by Dunnett's comparison test 

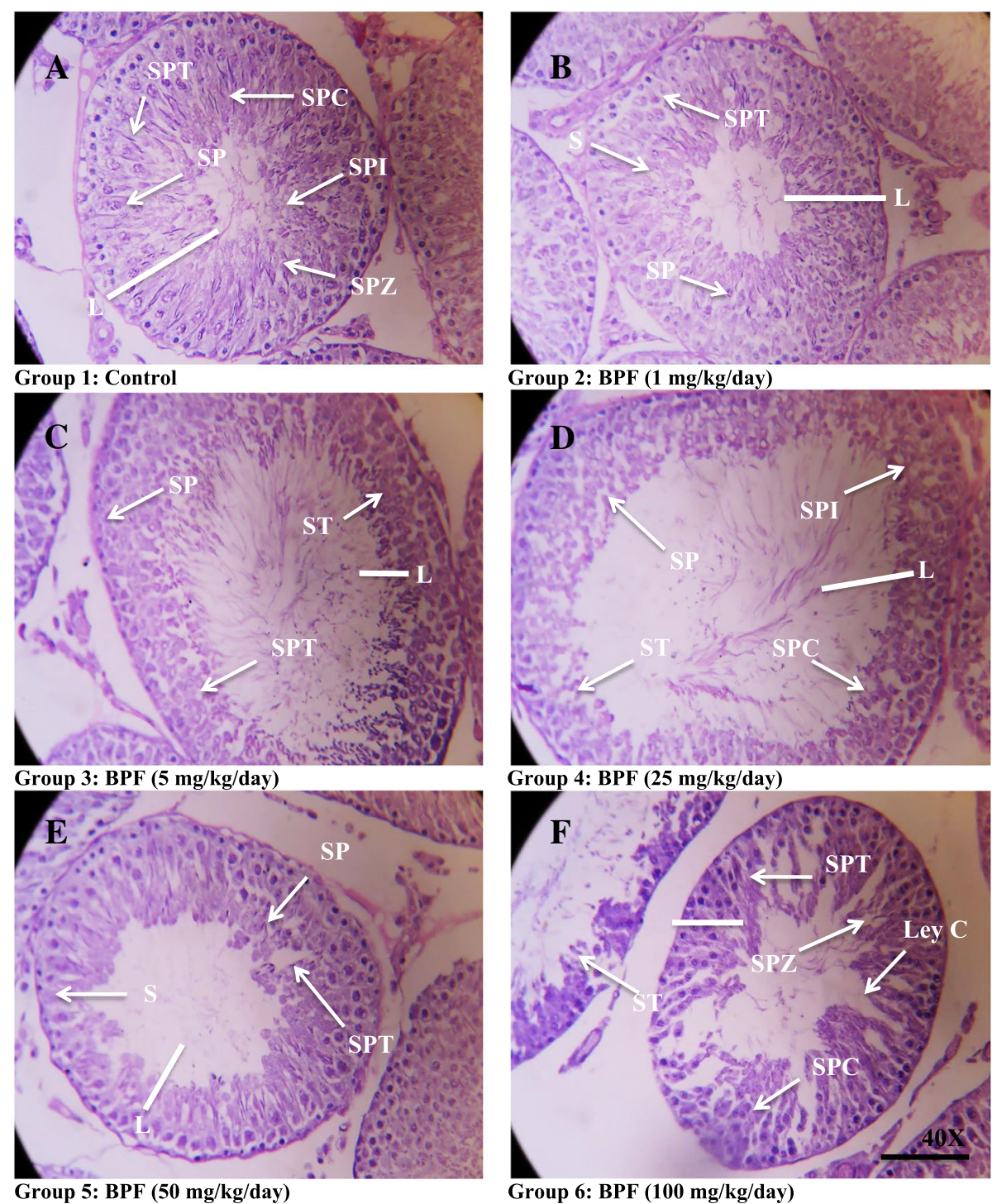

Group 4: BPF (25 mg/kg/day)

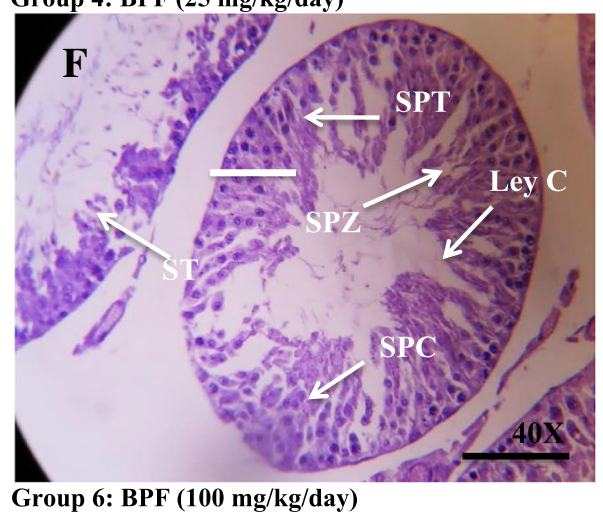

Fig. 1 Photomicrographs of rats testicular tissues of control and treated animals with different concentrations of BPF. The control (a) reveals normal germ cells: spermatogonia (SP), spermatocytes (SPC), spermatids (SPT), spermatozoa (SPZ). b-f Treated groups with BPF (1, 5, 25, 50, and $100 \mathrm{mg} / \mathrm{kg} / \mathrm{day}$ ) showing changes in the testicular tissues seminiferous tubules with epithelium (Line without arrowhead), showing change in the testicular parenchyma, absence of sperm in lumen, seminiferous tubules with germ cells, Leydig cells (LeyC), absence of sperm in lumen of tubules and spermatids. Presenting ST, seminiferous tubules; SP, spermatogonia; SPC, spermatocytes; SPT, spermatids; SPZ, spermatozoa; IT, interstitial tissue; LeyC, Leydig cell (White arrow). H\&E ( $\times 40)$

resulting toxic effects of these chemicals may affect the regulatory genes involved in the development of follicles in females and sperms in males. The consumption of $\mathrm{BPA}$ alternatives is at rising due to strict regulations on the use of BPA in some countries [27, 28]. A study suggested a possible association between BPA levels and increased risk of prosocial behavior and between MECPP levels and increased risk of conduct problems [29]. The structural similarity of BPF with BPA marks it as an endocrine disruptor and in vitro data has also revealed that BPF has a binding affinity with receptors which change the testosterone secretions in the fetal testis and can also induce cell proliferation. In vivo studies have shown that BPF influences the expression of sex hormone-regulated genes and also has developmental and reproductive effects in mammals. Recently published data regarding some of the BPA analogs has upturned concerns that whether the so-called safer analogs of BPA are more alarming to both human and wildlife [30]. In the present study, we conducted both in vivo and in vitro studies to evaluate the effects of BPF on the reproductive functions of male rats.

In the in vitro study, we incubated testicular tissues with different concentrations of BPF for 2 hours. The 

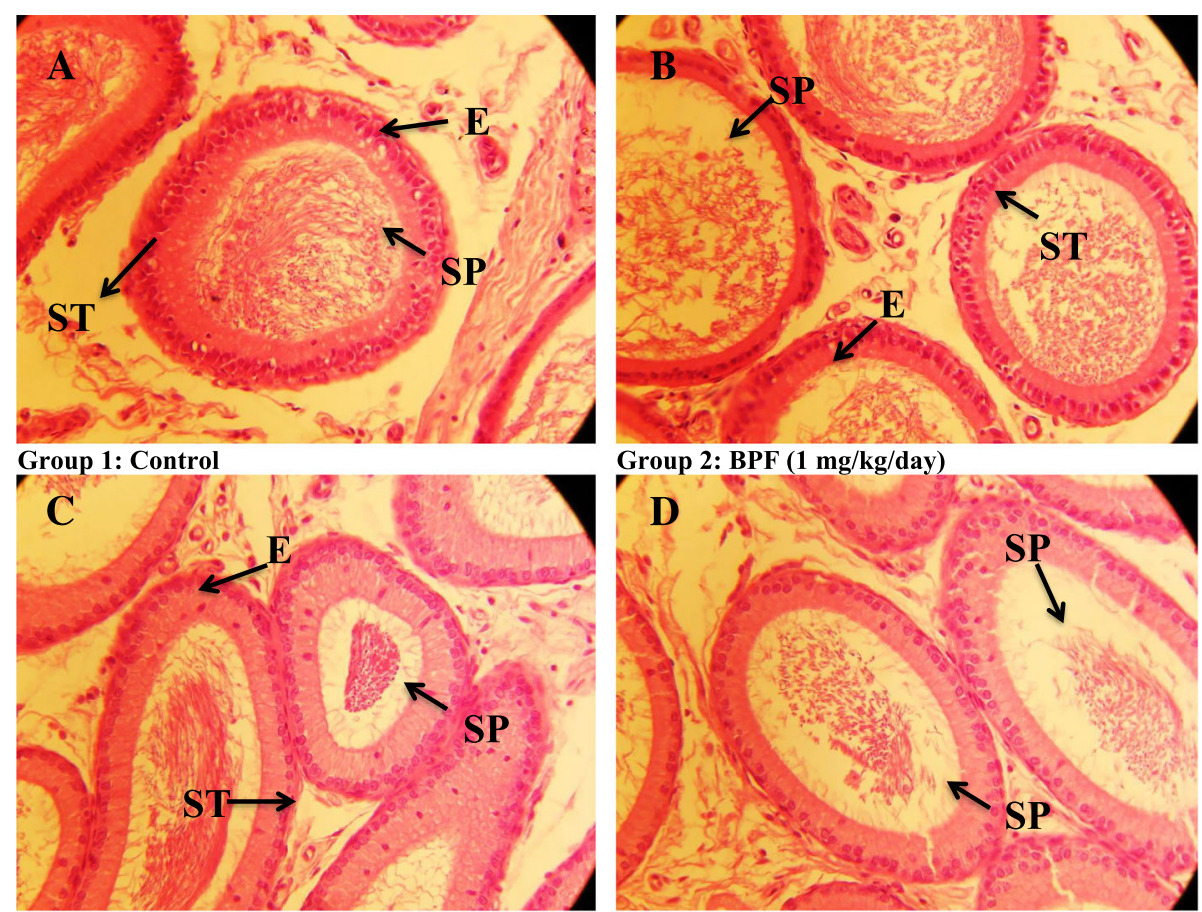

Group 2: BPF (1 mg/kg/day)
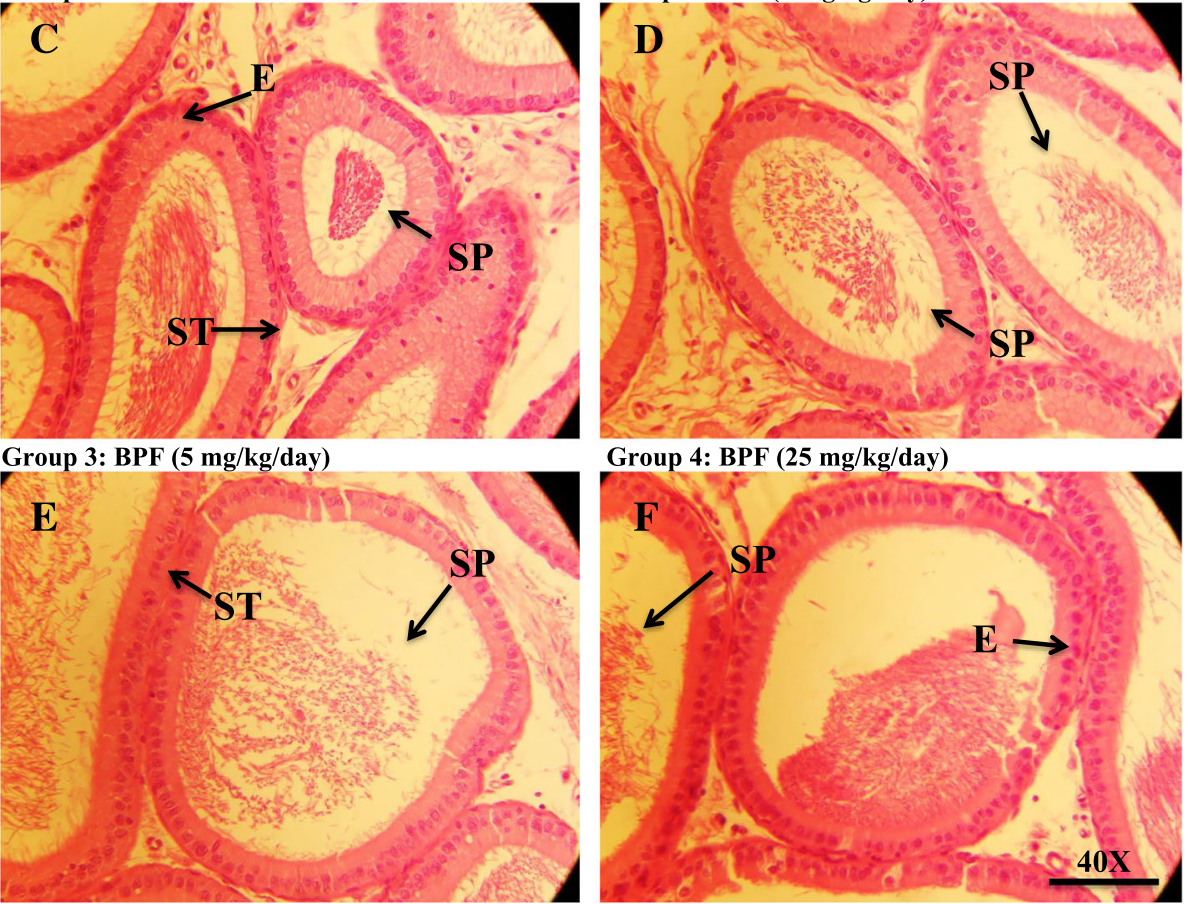

Group 4: BPF (25 mg/kg/day)

Group 5: BPF (50 mg/kg/day)

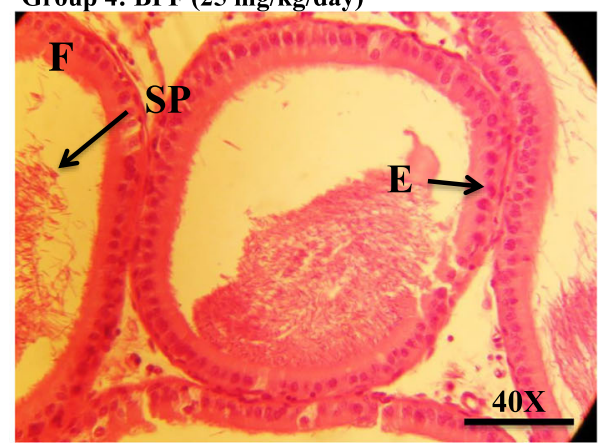

Group 6: BPF (100 mg/kg/day)

Fig. 2 Photomicrograph of caput epididymis tissue showing a control; with compact arrangement of caput tubules with sperm-filled lumen $\mathbf{b}$ BPF (1 mg/kg/day)-exposed group, presenting normal caput tubules like in the control. c BPF (5 mg/kg/day) exposed group showing seminiferous tubules with less number of sperm in the lumen (arrow). d BPF ( $25 \mathrm{mg} / \mathrm{kg} /$ day)-exposed group presenting caput tubules with empty lumen (arrow). Similarly, e BPF (50 mg/kg/day)-exposed group showing less number of sperms in the lumen. $\mathbf{f}$ BPF (100 mg/kg/day)-exposed group showing less number of sperms and empty lumen (arrow). Presenting SP, spermatozoa; ST, seminiferous tubules; E, epithelium. H\&E ( $\times 40)$

incubated tissues did not show any significant change on the antioxidant enzymes as CAT, SOD, and POD. BPA and its analogs have a toxic influence on the formation of ROS inside the body, and studies have also shown that these phenols not only increase in the levels of ROS but also lead into oxidative stress inside many cellular networks [31]. Similar to data reported in BPS, we observed increase ROS and lipid peroxidation in testicular tissues after exposure to BPF in vitro $[16,32]$. The results of the in vivo study showed dose-dependent effects of BPF on the oxidative stress in the reproductive system of male rats. The groups exposed to higher concentrations of BPF showed a significant difference in the histology of the reproductive tissues by reducing the sperm number in the epididymis and decreasing the height of epithelial tissues. Androgens also play an important role in the normal development of the male reproductive system [26, 33, 34]. BPF higher exposure groups were observed with an elevated level of testosterone which also leads to higher oxidative stress as compared to the lowdose-exposure groups.

Exposure to BPF caused induction of ROS which lead into an increase in the levels of LPO and activation of antioxidant enzymes which are in line with the earlier studies where BPA exposure degraded protein and altered antioxidant enzymes [35]. In the in vivo study, BPF exposure also increased the levels of LPO and also altered the levels of SOD and CAT which also indicated 

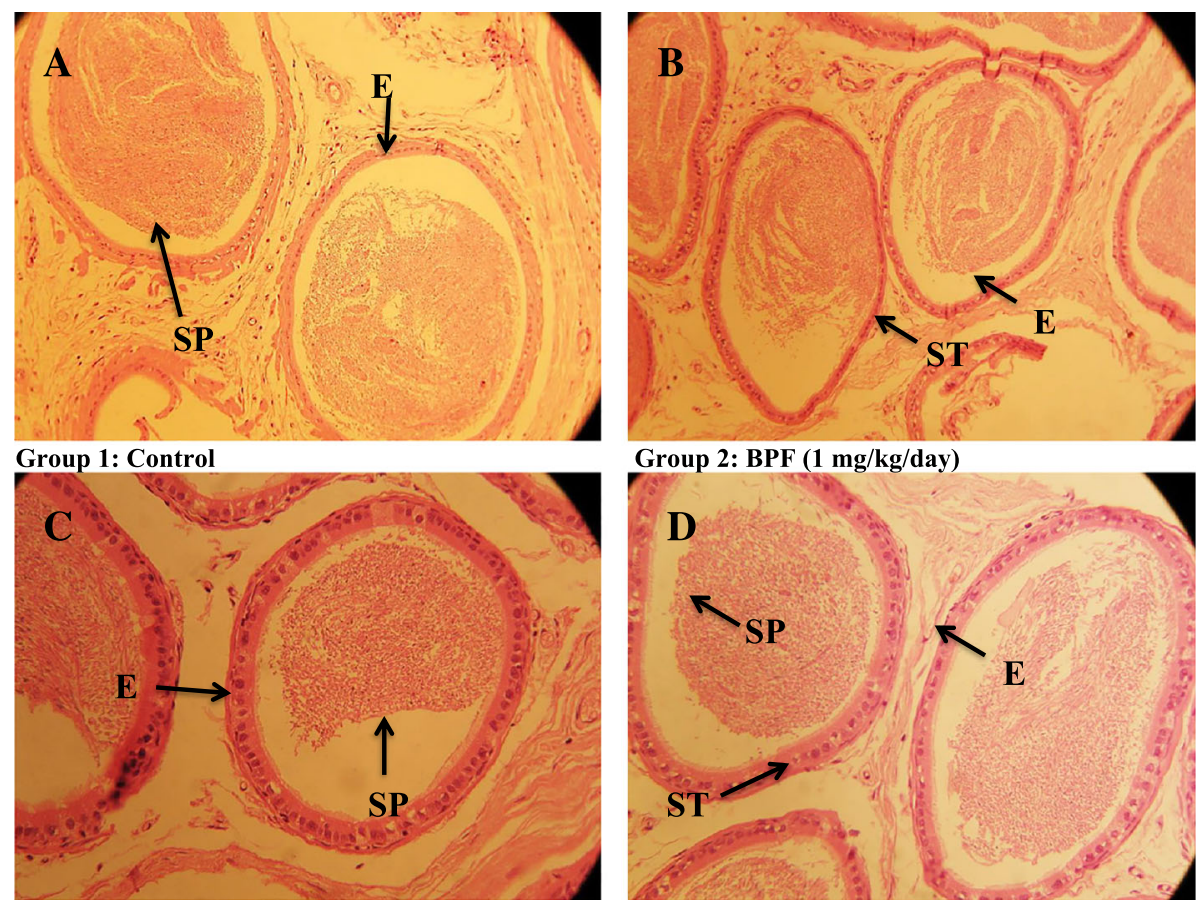

Group 2: BPF (1 mg/kg/day)
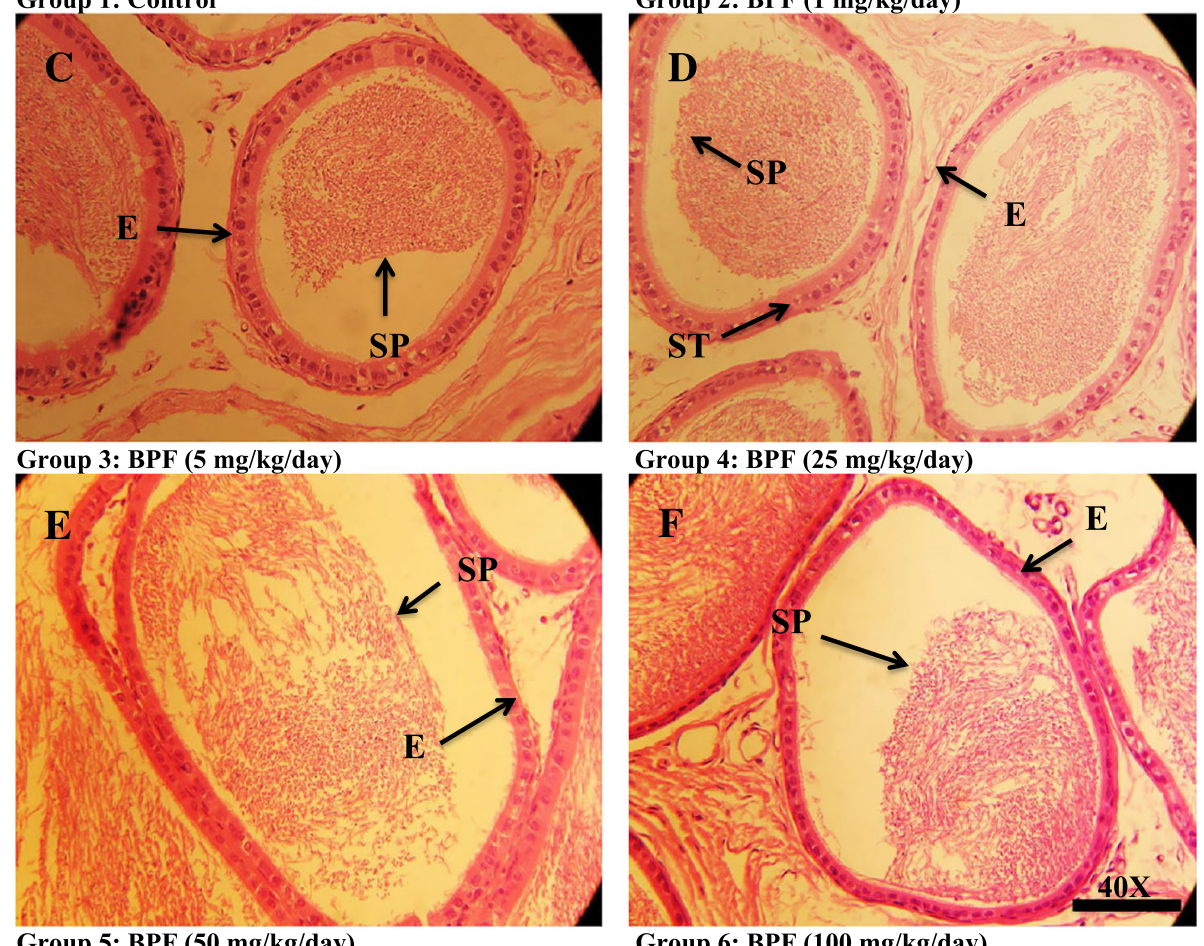

Group 5: BPF (50 mg/kg/day)

Group 6: BPF (100 mg/kg/day)

Fig. 3 Photomicrograph of cauda epididymis tissue showing a control; with compact arrangement of cauda tubules with sperm-filled lumen. $\mathbf{b}$ BPF (1 mg/kg/day)-exposed group, presenting normal caput tubules like in the control. c BPF ( $5 \mathrm{mg} / \mathrm{kg} /$ day)-exposed group, presenting cauda tubules with sperm-filled lumen. d BPF ( $25 \mathrm{mg} / \mathrm{kg} /$ day-exposed group presenting cauda tubules with less sperm in the lumen. Similarly, e BPF ( $50 \mathrm{mg} / \mathrm{kg} / \mathrm{day}$ )-exposed group presenting cauda tubules with fewer sperm in the lumen. Likewise, $\mathbf{f}$ BPF (100 mg/kg/day)-exposed group presenting cauda tubules with empty spaces and fewer number of sperm in the lumen. Presenting SP, spermatozoa, ST, seminiferous tubules; E, epithelium. H\&E $(\times 40)$

oxidative stress. This change occurred because of oxidative stress in the reproductive tissues caused by exposure of BPF different concentrations which also reduced the levels of proteins and antioxidant enzymes which are similar to the findings of some previous studies [36-39].

We observed the substantial change in both plasma and intra-testicular testosterone in the in vivo study. Our results are in accordance with previous researches which indicated altered levels of different hormones after exposure to BPA and some of its analogs [19, 34].

The process of Spermatogenesis is controlled by different reproductive hormones and cellular interactions inside the testes. ROS and disturbed antioxidant enzymes lead to disturbed spermatogenesis [40]. In the testicular tissues, we observed a reduction in the number of spermatids, alerted epithelial height and seminiferous tubules, and reduced concentrations of testosterone. Some previous studies are in accordance with our current study on the exposure of BPF where exposure to BPA and some of its analogs altered steroidogenesis and lead into oxidative stress in the different tissues $[19,34]$. Similarly, our current study results also showed that BPF not only alters spermatogenesis in the testis but also causes a reduction in the levels of testosterone secretions. Further studies are required both in vitro and in vivo which can show the molecular and cellular mechanisms of these BPA 
analogs specific response in the environmental hazard assessment which will let us better understand the mechanisms through which BPA analogs endocrine disruption on different tissues be analyzed.

\section{Conclusions}

The results of our present study showed that BPF at higher dose exposures may possibly have outcomes in oxidative stress and disturbed reproductive hormones. Thus, the use of BPA analogs should be carried out with caution, especially until the effective risk assessment is conducted. Further studies need to analyze the molecular basis of these alterations both in vivo and in vitro studies which will let us understand how BPF can still have an effect on the physiology of different tissues inside the body.

\section{Acknowledgments}

We are grateful to the Deanship of Scientific Research at King Saud University for its support of this research through Research Group Project number 193.

\section{Authors' contributions \\ $A U$ and SJ designed the study, conceived the study, and analyzed the results. AU conceived an initial part of the study, performed the experiment, and helped in compiling the results. SR helped in writing the results. SJ, SR, $M P$, and TA wrote the paper with input from all other authors. AU, SR, TA, $\mathrm{MP}$, and AA made a substantial contribution in the interpretation of data and revising the manuscript for intellectual content. All authors read and approved the final manuscript.}

\section{Funding}

The project was partially funded by the Higher Education Commission (HEC) of Pakistan. We are grateful to the Deanship of Scientific Research at King Saud University for its funding of this research through Research Group Project number 193 in designing and data interpretation.

\section{Availability of data and materials}

Not applicable

\section{Ethics approval and consent to participate}

This study makes use of animals and the experimental protocol was approved (BAS\#0256) by the ethical board of Quaid-i-Azam University, Islamabad, Pakistan.

\section{Consent for publication}

Not applicable

\section{Competing interests}

The authors declare that they have no competing interests.

Received: 16 December 2018 Accepted: 29 May 2019

Published online: 10 June 2019

\section{References}

1. Geens T, Goeyens L, Covaci A. Are potential sources for human exposure to bisphenol-a overlooked? Int J Hyg Environ Health. 2011;214(5):339-47.

2. Geens T, Apelbaum TZ, Goeyens L, Neels H, Covaci A. Intake of bisphenol A from canned beverages and foods on the Belgian market. Food Addit Contam. 2010;27(11):1627-37.

3. Kang J-H, Kondo F, Katayama Y. Human exposure to bisphenol A. Toxicol. 2006;226(2-3):79-89.

4. Commission E. Commission Regulation (EU) No 10/2011 of 14 January 2011 on plastic materials and articles intended to come into contact with food. Off J Eur Union. 2011;12:1-89.

5. Liao C, Liu F, Alomirah H, Loi VD, Mohd MA, Moon H-B, Nakata H, Kannan K. Bisphenol $\mathrm{S}$ in urine from the United States and seven Asian countries: occurrence and human exposures. Environ Sci Technol. 2012;46(12):6860-6.
6. Viñas P, Campillo N, Martínez-Castillo N, Hernández-Córdoba M. Comparison of two derivatization-based methods for solid-phase microextraction-gas chromatography-mass spectrometric determination of bisphenol A, bisphenol S and biphenol migrated from food cans. Anal Bioanal Chem. 2010;397(1):115-25.

7. Rosenmai AK, Dybdahl M, Pedersen M, Alice van Vugt-Lussenburg BM, Wedebye EB, Taxvig C, Vinggaard AM. Are structural analogues to bisphenol a safe alternatives? Toxicol Sci. 2014;139(1):35-47.

8. Cirillo T, Latini G, Castaldi MA, Dipaola L, Fasano E, Esposito F, Scognamiglio G, Francesco FD, Cobellis L. Exposure to di-2-ethylhexyl phthalate, di-n-butyl phthalate and bisphenol A through infant formulas. J Agric Food Chem. 2015;63(12):3303-10.

9. Ye X, Kuklenyik Z, Needham LL, Calafat AM. Automated on-line columnswitching HPLC-MS/MS method with peak focusing for the determination of nine environmental phenols in urine. Anal Chem. 2005;77(16):5407-13.

10. Ye X, Wong L-Y, Kramer J, Zhou X, Jia T, Calafat AM. Urinary concentrations of bisphenol $\mathrm{A}$ and three other bisphenols in convenience samples of US adults during 2000-2014. Environ Sci Technol. 2015;49(19):11834-9.

11. Cabaton N, Zalko D, Rathahao E, Canlet C, Delous G, Chagnon M-C, Cravedi J-P, Perdu E. Biotransformation of bisphenol F by human and rat liver subcellular fractions. Toxicol in Vitro. 2008;22(7):1697-704.

12. Cabaton N, Dumont C, Severin I, Perdu E, Zalko D, Cherkaoui-Malki M, Chagnon M-C. Genotoxic and endocrine activities of bis (hydroxyphenyl) methane (bisphenol F) and its derivatives in the HepG2 cell line. Toxicol. 2009;255(1-2):15-24.

13. Gramec Skledar D, Troberg J, Lavdas J, Peterlin Mašič L, Finel M. Differences in the glucuronidation of bisphenols $F$ and $S$ between two homologous human UGT enzymes, 1 A9 and 1A10. Xenobiotica. 2015;45(6):511-9.

14. Cabaton N, Chagnon M-C, Lhuguenot J-C, Cravedi J-P, Zalko D. Disposition and metabolic profiling of bisphenol $\mathrm{F}$ in pregnant and nonpregnant rats. J Agric Food Chem. 2006;54(26):10307-14.

15. Hulak M, Gazo I, Shaliutina A, Linhartova P. In vitro effects of bisphenol A on the quality parameters, oxidative stress, DNA integrity and adenosine triphosphate content in sterlet (Acipenser ruthenus) spermatozoa. Comp Biochem Physiol Part C Toxicol Pharmacol. 2013;158(2):64-71.

16. Ullah H, Jahan S, Ain QU, Shaheen G, Ahsan N. Effect of bisphenol S exposure on male reproductive system of rats: a histological and biochemical study. Chemosphere. 2016;152:383-91.

17. Ullah A, Pirzada M, Jahan S, Ullah H, Shaheen G, Rehman H, Siddique MF, Butt MA. Bisphenol A and its analogs bisphenol B, bisphenol F, and bisphenol S: comparative in vitro and in vivo studies on the sperms and testicular tissues of rats. Chemosphere. 2018;209:508-16.

18. Heindel JJ, Newbold RR, Bucher JR, Camacho L, Delclos KB, Lewis SM, Vanlandingham M, Churchwell MI, Twaddle NC, McLellen M. NIEHS/FDA CLARITY-BPA research program update. Reprod Toxicol. 2015;58:33-44.

19. Ullah A, Pirzada M, Jahan S, Ullah H, Turi N, Ullah W, Siddiqui MF, Zakria M, Lodhi KZ, Khan MM. Impact of low-dose chronic exposure to bisphenol A and its analogue bisphenol $\mathrm{B}$, bisphenol $\mathrm{F}$ and bisphenol $\mathrm{S}$ on hypothalamo-pituitary-testicular activities in adult rats: a focus on the possible hormonal mode of action. Food Chem Toxicol. 2018;121:24-36.

20. Afsar T, Razak S. Modulatory influence of Acacia hydaspica R. Parker ethyl acetate extract against cisplatin inveigled hepatic injury and dyslipidemia in rats. BMC Complement Altern Med. 2017;17(1):307.

21. Afsar T, Razak S, Almajwal A, Khan MR. Acacia hydaspica R. Parker ameliorates cisplatin induced oxidative stress, DNA damage and morphological alterations in rat pulmonary tissue. BMC Complement Altern Med. 2018;18(1):49

22. Carlberg I, Mannervik E. Glutathione concentration in rat brain. J Biol Chem. 1975;250:4475-80.

23. Iqbal M, Sharma S, Rezazadeh H, Hasan N, Abdulla M, Athar M. Glutathione metabolizing enzymes and oxidative stress in ferric nitrilotriacetate mediated hepatic injury. Redox Rep. 1996;2(6):385-91.

24. Hayashi I, Morishita Y, Imai K, Nakamura M, Nakachi K, Hayashi T. Highthroughput spectrophotometric assay of reactive oxygen species in serum. Mutat Res Genet Toxicol Environ Mutagen. 2007;631(1):55-61.

25. Jensen EC. Quantitative analysis of histological staining and fluorescence using ImageJ. Anat Rec. 2013;296(3):378-81.

26. Lee HJ, Chattopadhyay S, Gong E-Y, Ahn RS, Lee K. Antiandrogenic effects of bisphenol $\mathrm{A}$ and nonylphenol on the function of androgen receptor. Toxicol Sci. 2003;75(1):40-6.

27. Minatoya M, Itoh S, Miyashita C, Araki A, Sasaki S, Miura R, Goudarzi H, Iwasaki Y, Kishi R. Association of prenatal exposure to perfluoroalkyl 
substances with cord blood adipokines and birth size: the Hokkaido study on environment and children's health. Environ Res. 2017;156:175-82.

28. Kishi R, Araki A, Minatoya M, Hanaoka T, Miyashita C, Itoh S, Kobayashi S, Bamai YA, Yamazaki K, Miura R. The Hokkaido birth cohort study on environment and children's health: cohort profile-updated 2017. Environ Health Prev Med. 2017;22(1):46.

29. Minatoya M, Itoh S, Yamazaki K, Araki A, Miyashita C, Tamura N, Yamamoto J, Onoda Y, Ogasawara K, Matsumura T. Prenatal exposure to bisphenol $\mathrm{A}$ and phthalates and behavioral problems in children at preschool age: the Hokkaido Study on Environment and Children's Health. Environ Health Prev Med. 2018;23(1):43.

30. Eladak S, Grisin T, Moison D, Guerquin M-J, N'Tumba-Byn T, Pozzi-Gaudin S, Benachi A, Livera G, Rouiller-Fabre V, Habert R. A new chapter in the bisphenol A story: bisphenol $\mathrm{S}$ and bisphenol $\mathrm{F}$ are not safe alternatives to this compound. Fertil Steril. 2015;103(1):11-21.

31. Wu M, Xu H, Shen Y, Qiu W, Yang M. Oxidative stress in zebrafish embryos induced by short-term exposure to bisphenol A, nonylphenol, and their mixture. Environ Toxicol Chem. 2011;30(10):2335-41.

32. Maćczak A, Cyrkler M, Bukowska B, Michałowicz J. Eryptosis-inducing activity of bisphenol A and its analogs in human red blood cells (in vitro study). J Hazard Mater. 2016;307:328-35.

33. Holdcraft RW, Braun RE. Hormonal regulation of spermatogenesis. Int J Androl. 2004;27(6):335-42.

34. Manfo FPT, Jubendradass R, Nantia EA, Moundipa PF, Mathur PP. Adverse effects of bisphenol A on male reproductive function. In: Rev Environ Cont Toxicol Vol 228. edn: Springer; 2014. p. 57-82.

35. Kaur S, Saluja M, Bansal M. Bisphenol A induced oxidative stress and apoptosis in mice testes: modulation by selenium. Andrologia. 2018;50(3):e12834.

36. Radák Z, Kaneko T, Tahara S, Nakamoto H, Ohno H, Sasvári M, Nyakas C, Goto $\mathrm{S}$. The effect of exercise training on oxidative damage of lipids, proteins, and DNA in rat skeletal muscle: evidence for beneficial outcomes. Free Radic Biol Med. 1999;27(1):69-74.

37. Maćczak A, Cyrkler M, Bukowska B, Michałowicz J. Bisphenol A, bisphenol S, bisphenol $\mathrm{F}$ and bisphenol $\mathrm{AF}$ induce different oxidative stress and damage in human red blood cells (in vitro study). Toxicol in Vitro. 2017:41:143-9.

38. Usman A, Ahmad M. From BPA to its analogues: is it a safe journey? Chemosphere. 2016;158:131-42.

39. Michałowicz J, Mokra K, Bąk A. Bisphenol A and its analogs induce morphological and biochemical alterations in human peripheral blood mononuclear cells (in vitro study). Toxicol in Vitro. 2015;29(7):1464-72.

40. Sanocka D, Kurpisz M. Reactive oxygen species and sperm cells. Reprod Biol Endocrinol. 2004;2(1):12.

\section{Publisher's Note}

Springer Nature remains neutral with regard to jurisdictional claims in published maps and institutional affiliations.

Ready to submit your research? Choose BMC and benefit from:

- fast, convenient online submission

- thorough peer review by experienced researchers in your field

- rapid publication on acceptance

- support for research data, including large and complex data types

- gold Open Access which fosters wider collaboration and increased citations

- maximum visibility for your research: over $100 \mathrm{M}$ website views per year

At BMC, research is always in progress.

Learn more biomedcentral.com/submissions 